\title{
Research on the Development of Festivals in Heilongjiang Province from the Perspective of Global Tourism
}

\author{
Du Zewen ${ }^{1, \text { a }}$, Jiang Hongyang ${ }^{2, ~ b}$, Bai Yunkai ${ }^{3, c}$ \\ ${ }^{1}$ Post Doctoral Mobile Station for Business Administration, Harbin University of Commerce, Harbin, 150028, \\ China \\ ${ }^{2,3}$ School of Management, Harbin University of Commerce, Harbin, 150028, China \\ adzw03921@163.com, b1071526055@qq.com, '924151194@ qq.com
}

Keywords: Heilongjiang; Global tourism; Festival.

\begin{abstract}
At present, the tourism industry is developing rapidly, and global tourism has become a new stage of tourism development. As a famous tourist province, Heilongjiang Province should increase its development and attention to global tourism. Therefore, how to properly combine the whole world tourism and festival activities requires a comprehensive study from the theoretical level to the practical field. This paper takes Heilongjiang Province as a case study, and uses literature collection, summarization and other research methods to discuss the whole world tourism in Heilongjiang Province, in order to promote the sustainable development of festival tourism in Heilongjiang Province.
\end{abstract}

\section{Introduction}

With the continuous development of tourism, the benefits brought by tourism have become an extremely important part of the economic composition of most provinces and cities. As a famous tourist province in China, Heilongjiang has not stopped innovating before the new opportunities are faced, and it is only a tourist that stays in the traditional mode. The whole world is promoting global tourism and national festival tourism, but the development of tourism in Heilongjiang Province is not mature and lacks specific research and analysis of global tourism. Taking Heilongjiang Province as an example, this paper studies the development of national festivals in Heilongjiang Province from the perspective of global tourism, and aims at the current situation and existing problems of festival tourism development in Heilongjiang Province. It analyzes the development strategy of festival tourism and hopes to have important guiding significance for the development of tourism in Heilongjiang Province

\section{Literature Review}

Sandra believes that the sustainable development of tourism is conducive to rational development [1]; Carmen Padin believes that sustainable tourism planning plays an important role in promoting the sustainable development of tourism [2]; Carmen Padin takes the Connie Marathon in western Ireland The rural tourism is the research object, pointing out that the local network technology and the level of community residents' participation in tourism development are important factors affecting the sustainable development of the village [2]; Hashemi explores the sustainable development of rural tourism from the two dimensions of space and time. The course [3]. Katanyu (2012) believes that the level of purchase behavior and marketing mix can affect the level of travel services [4]. “Global Tourism” is a new tourism development concept advocated by China's tourism industry. Li Xinjian proposed the connotation of the global tourism concept, and believed that global tourism is a new concept of resources, products, industries and markets [5]; in 2016, Li Jinzao, director of the National Tourism Administration, proposed that China's tourism development must be from "tourism tourism”. Turn to "global travel." After making comments, all localities under the guidance of the 
concept of "global tourism" broke the restrictions of the scenic spot and made specific tourism planning [6]. Due to the short time proposed by this concept, up to now, there is no clear concept in the domestic academic circles about global tourism. This paper will systematically analyze and discuss the development of festivals in Heilongjiang Province from the perspective of global tourism.

\section{The Current Situation of Heilongjiang Province's Festivals from the Perspective of Global Tourism}

\subsection{Composition of Heilongjiang Province Tourism Festival.}

In the development of tourism products, Heilongjiang Province took the lead in completing the survey of tourism resources in the country, and based on this, strengthened the tourism planning and project library construction. The province adheres to the principle of joint development, open development and diversified investment. Relying on resource advantages and facing market demand, it has invested in 284 basic construction projects and developed more than 300 tourism products around the formation of the province's tourism framework and key tourist routes. A series of special tourism products such as ice lamp snow viewing, skiing, hunting, rafting, recuperation, summer health care, environmental ecology, historical sites, ethnic customs, border crossings and so on. Major tourism festivals such as China Heilongjiang International Ski Festival, China Harbin International Ice and Snow Festival, Jingbo Lake Golden Autumn Festival, Yichun Forest Ecological Tourism Festival and Wudalian Volcano Tourism Festival have been well-known at home and abroad. The province has now formed Based on Russia, Japan, South Korea and Southeast Asia are short-distance markets, Europe and the United States are the national source market for remote markets and the overseas customer market in Hong Kong, Macao and Taiwan. In the development of the domestic market, the basic market in the province has been formed. The proximity of the Bohai Bay short-haul market and the southeast coastal area to the remote source market, and gradually extended to the central and western regions.

\subsection{Have their Own Unique Folk Culture.}

The development of minority folklore tourism in Heilongjiang Province has enormous resource advantages. Its folk tourism resources are characterized by various types, concentrated distribution and unique cultural connotations. It is an important resource condition for the development of folk tourism. There are many types of ethnic folk customs in Heilongjiang Province. There are many ethnic minorities in Heilongjiang Province, and the folk resources in Heilongjiang Province are rich and diverse. The tourism resources of ethnic minority folk culture in Heilongjiang Province include planting culture, fishing and hunting culture, nomadic culture, commercial culture and handicraft industry, as well as the essence of traditional culture of clothing, food, housing and transportation. The folk customs of life reflect the characteristics of ethnic minorities such as clothing, food, housing, and transportation. The ethnic minority costumes are rich and varied, with diverse food and customs, strong folk customs, rare buildings and unique traditional folk customs. Manchu cheongsam, Korean white clothes, Hezhe fish skin clothing, Oroqen animal leather clothing and other cultural content. Manchu sauerkraut, kimchi and Hezhe fish food have unique flavors. The "Ji" room of the Datun people, the original culture of the living culture such as the "Xianrenzhu" of the Oroqen people, the Mongolian Lele car, the Orochun dog sled and other traffic cultures are full of fun.

\section{Problems in the Development of Festivals in Heilongjiang Province}

\subsection{Unreasonable Distribution and Utilization of Tourism Resources.}

At this stage, the tourism resources of Heilongjiang Province seem to have been fully developed, but from the perspective of overall efficiency, there are still unreasonable places in resource allocation and utilization. Some tourism resources are underdeveloped and the overall level of resource development is not high. In addition to the provincial capital Harbin, many areas have poor 
tourist facilities and large construction areas. In addition, the tourist routes are long, the development of scenic spots is poor, the service facilities are not matched, the development of landscape resources is relatively simple, resulting in waste of resources, lack of systematic development, poor awareness of resource protection in the development process, and the destruction of tourism resources still exists. For example, due to the surge in tourism resources, the scenic spots in Jingpo Lake have not been restricted in time, resulting in serious damage to some scenic spots and the disintegration of the ecosystem, which will affect the later development. Due to wind erosion, acidification and other reasons, some historical relics have not been protected and need to be repaired in time.

\subsection{Characteristic Culture is not Prominent.}

Heilongjiang Province is rich in history and culture, but Heilongjiang Province lacks the propaganda and development of its own unique culture. Most historical and cultural theme parks lack cultural uniqueness from design, interpretation and explanation. For example, Heilongjiang is the place where the Manchu ancestors labored, lived and proliferated in China, but the so-called Manchu cultural characteristics were seriously lacking, even worse than Changchun. The mention of Changchun cultural characteristics would make people think of the Puppet Manchurian Palace quickly. Heilongjiang culture also has patriotic historical themes such as World War II, anti-union, and territorial disputes in Heilongjiang. However, due to the lack of attention to development, the content fusion effect is not good, and the propaganda is insufficient. Moreover, Heilongjiang Province does not have a more detailed description of the period of the exhibition.

\section{Countermeasures}

\subsection{Design a Unique Ice and Snow Tourism Product.}

The snow and ice in Heilongjiang Province is spread all over the country. There are two kinds of ice and snow tourism products, one is for tourists to visit and the other is for special tourism products. For example, tourists come to the world of ice and snow to experience the joy brought by ice and snow. Heilongjiang ice and snow tourism products also include this. Two.

The ice and snow products of Heilongjiang should be the most mature development, but the ice and snow products are mainly Harbin. The other places do not have good excavation and development of ice and snow. Harbin ice and snow products are facing double competition at home and abroad. As far as ski competition is concerned, Beijing's ski resorts have excellent snow quality, and the special geographical location constitutes a great competitive pressure on Heilongjiang Province. Harbin's ice and snow product management needs to be further improved, and the distance between scenic spots and scenic spots will be pulled. Recently, to solve the problem of traffic congestion, the low temperature inside the scenic spots, such as ice and snow, has yet to be resolved. Some heating equipment is added inside the scenic spots. The prices of food and shelter around the tourist area must be strictly controlled, so that many tourists can enjoy themselves.

\subsection{Give Full Play to the Characteristics of "the Capital of Music".}

The world-famous "music capital" of Vienna and the cities of Glasgow and Italy, which are renowned for the "music capital" of the United Nations, have developed a unique urban music culture development plan, which has promoted the promotion of the "music capital" brand and promotion. Very good role. Harbin is the first city in China and even Asia to be awarded the "Music Capital" by the United Nations. It is suggested that the relevant government departments should actively study and formulate the "Music Capital" construction plan in line with Harbin's actual situation on the basis of full research and argumentation, reflecting the city's personality characteristics. The "Music City" construction plan should cooperate with the new strategy of the municipal party committee as much as possible, and cooperate with the tourism industry planning, especially the Songhua River wetland tourism industry planning. It is linked to the planning of the cultural industry and the construction of the "urban cultural city". In order to ensure the continuity and authority of the plan, it should be 
determined in the form of legislation of the National People's Congress.

\subsection{Event Planning Combining Tradition and Fashion.}

There is a certain difference between Chinese traditional culture and modern culture and it is accompanied by interactive development. Since the reform and opening up, traditional festivals and modern festivals have influenced each other. Studying traditional festivals and modern festivals is conducive to promoting traditional festivals, creating modern festival brands, promoting the development of festival economy and festival culture, and promoting the construction of a harmonious spiritual home. Traditional festivals can be said to be deeply rooted in people's hearts, which is unmatched by modern festivals. Traditional festivals can be said to be deeply rooted in people's hearts. However, for festivals to develop, modern festivals are indispensable. Therefore, it is necessary to tap and draw on the essence and success of traditional festivals to promote the development of modern festivals.

\section{Conclusions}

Tourism is booming rapidly, and global tourism is bound to become a major trend in the future. This study takes Heilongjiang Province as a case, from the current situation of Heilongjiang Province's global tourism and festival development, existing problems and their causes, and adopted In-depth research on various aspects such as countermeasures. The following conclusions are drawn: First, the development of festivals in Heilongjiang Province must integrate natural resources and human resources. Second, vigorously promote the integration of urban and rural development in Heilongjiang Province. Third, comprehensively innovate and meticulously create festivals with special features.

\section{Acknowledgements}

This work was financially supported by the Heilongjiang Province Philosophy and Social Science Research Planning Project (16GLB09); National Natural Science Foundation of China (71602042); Humanities and Social Sciences Research Project of the Ministry of Education (Youth Fund Project) (14YJC630142); Harbin University of Commerce Ph.D. Research Project (14RW18); Harbin University of Commerce Project "Modern Service Industry Supporting Longjiang Revitalization Development Research” (hx2016001); 2016 Harbin University of Commerce Youth Innovation Talent Support Project (2016QN009); Harbin University of Commerce's Postdoctoral Research Support Program (2017BSH024).

\section{References}

[1] Sandra Lima Cortez. Strategies for the development of sustainable tourism in the Amazon rainforest of Bolivia [J].Worldwide hospitality and Tourism Themes, 2010:22.

[2] Carmen Padin. A sustainable tourism planning model: components and relatationships [J].European Business Review, 2012:246.

[3] Tsung Hung Lee, Hsieh. Indicators of sustainable tourism: A Case study from a Taiwan’s Wetlans [J]. Ecological Indicators, 2016:130.

[4] Yan Li. The Research of Regional Tourism Festival Activities Impact on Urban Development [A]. Information Engineering Research Institute, USA. Proceedings of 2013 3rd International Conference on Education and Education Management(EEM 2013) Volume 25[C].Information Engineering Research Institute,USA:,2013:4.

[5] Li Xinjian, Zhang Lingyun, Cui Li. Global Tourism: Idea Innovation for Building a World-Class Tourism Destination-In Beijing, for example[J].Human geography,2013,28(3):130-134. (In Chinese) 
[6] Yu Jie,Hu Jing,Zhu Lei,Lu Wen,Zhao Yue,Wang Kai. Progress and Prospects of Domestic Global Tourism Research [J].Tourism research, 2016, 8(6):86-91. (In Chinese) 